\title{
Mast cells in the pathophysiology of Duchenne muscular dystrophy in Golden Retriever $\operatorname{dog} \mathbf{s}^{1}$
}

\author{
Isabela M. Martins ${ }^{2}$, Lygia M.M. Malvestio 2,3, Jair R. Engracia-Filho ${ }^{4}$, \\ Gustavo S. Claudiano ${ }^{2,5}$ (D), Flávio R. Moraes ${ }^{2}$ and Julieta R.E. Moraes ${ }^{2 *}$ (D)
}

\begin{abstract}
Martins I.M., Malvestio L.M.M., Engracia-Filho J.R., Claudiano G.S., Moraes F.R. \& Moraes J.R.E. 2020. The role of mast cells in the pathogenesis of Duchenne muscular dystrophy in Golden Retriever dogs. Pesquisa Veterinária Brasileira 40(10):791-797. Departamento de Patologia Veterinária, Faculdade de Ciências Agrárias e Veterinárias, Universidade Estadual Paulista "Júlio de Mesquita Filho", Via Prof. Paulo Donato Castellane Km 5, Jaboticabal, SP 14884-900, Brazil. E-mail: julietaengracia@gmail.com

The Golden Retriever muscular dystrophy (GRMD) is one of the best models of Duchenne muscular dystrophy (DMD), with similar genotypic and phenotypic manifestations. Progressive proliferation of connective tissue in the endomysium of the muscle fibers occurs in parallel with the clinical course of the disease in GRMD animals. Previous studies suggest a relationship between mast cells and the deposition of fibrous tissue due to the release of mediators that recruit fibroblasts. The aim of this study was to evaluate the presence of mast cells and their relationship with muscle injury and fibrosis in GRMD dogs of different ages. Samples of muscle groups from six GRMD and four control dogs, aged 2 to 8 months, were collected and analyzed. The samples were processed and stained with HE, toluidine blue, and Azan trichrome. Our results showed that there was a significant increase in infiltration of mast cells in all muscle groups of GRMD dogs compared to the control group. The average number of mast cells, as well as the deposition of fibrous tissue, decreased with age in GRMD dogs. In the control group, all muscle types showed a significant increase in the amount of collagenous tissue. This suggests increased mast cell degranulation occurred in younger GRMD dogs, resulting in increased interstitial space and fibrous tissue in muscle, which then gradually decreased over time as the dogs aged. However, further studies are needed to clarify the role of mast cells in the pathogenesis of fibrosis.
\end{abstract}

INDEX TERMS: Mast cells, pathogenesis, Duchenne muscular dystrophy, Golden Retriever dogs, canine, dogs, fibrosis, mast cells, muscular dystrophy.

RESUMO.- [O papel dos mastócitos na patogênese da distrofia muscular de Duchenne em cães Golden Retriever.] 0 cão Golden Retriever distrófico (Golden Retriever muscular dystrophy - GRMD) é um dos melhores modelos da distrofia

\footnotetext{
${ }^{1}$ Received on March 12, 2020.

Accepted for publication on April 23, 2020.

${ }^{2}$ Departamento de Patologia Veterinária, Faculdade de Ciências Agrárias e Veterinárias, Universidade Estadual Paulista "Júlio de Mesquita Filho" (Unesp), Via Prof. Paulo Donato Castellane Km 5, Jaboticabal, SP 14884-900, Brazil. *Corresponding author: julietaengracia@gmail.com

${ }^{3}$ Escola de Medicina Veterinária, IMED, Rua Gen. Prestes Guimarães 304, Vila Rodrigues, Passo Fundo, RS 99070-220, Brazil.

${ }^{4}$ Graduate Program in Animal Science, Escola de Ciências da Vida, Pontifícia Universidade Católica (PUC), Rua Imaculada Conceição 1155, Prado Velho, Curitiba, PR 80215-901, Brazil.

${ }^{5}$ Instituto de Biodiversidade e Florestas, Universidade Federal do Oeste do Pará (UFOPA), Campus Santarém, Av. Vera Paz s/n, Santarém, PA 68035-110, Brazil.
}

muscular de Duchenne (DMD), com manifestações genotípicas e fenotípicas similares. A proliferação progressiva de tecido conjuntivo no endomísio das fibras musculares ocorre paralelamente ao curso clínico da doença em animais GRMD. Estudos anteriores sugerem uma relação entre os mastócitos e a deposição de tecido fibroso devido à liberação de mediadores que recrutam fibroblastos. 0 objetivo deste estudo foi avaliar a presença de mastócitos e sua relação com a lesão muscular e fibrose em cães GRMD de diferentes idades. Amostras de grupos musculares de seis GRMD e quatro controles, com idade entre 2 a 8 meses, foram coletadas e analisadas. As amostras foram processadas e coradas com HE, azul de toluidina e tricrômico de Azan. Nossos resultados mostraram que houve um aumento significativo na infiltração de mastócitos em todos os grupos musculares de cães GRMD em comparação com o grupo controle. 0 número médio de mastócitos, assim 
como a deposição de tecido fibroso, diminuiu com a idade em cães GRMD. No grupo controle, todos os tipos musculares mostraram um aumento significativo na quantidade de tecido colágeno. Isto sugere o aumento da degranulação de mastócitos em cães GRMD mais jovens, resultando em aumento do espaço intersticial e tecido fibroso no músculo, que então gradualmente diminuiu com o tempo à medida que os cães envelheceram. No entanto, mais estudos são necessários para esclarecer o papel dos mastócitos na patogênese da fibrose.

TERMOS DE INDEXAÇÃO: Mastócitos, patogênese, distrofia muscular de Duchenne, cães Golden Retriever, caninos, fibrose, mastócitos.

\section{INTRODUCTION}

Duchenne muscular dystrophy (DMD) is a degenerative disease in humans caused by a mutation in the dystrophin gene, affecting one in every 3,500 male live births. DMD is $\mathrm{X}$-linked recessive genetic disorder located on the short arm of the X chromosome (Xp21) (Hoffman et al. 1987, Woolf et al. 2006). The first stage of the disease is characterized by focal groups of necrotic muscle fibers and muscle hypertrophy. Later, repeated cycles of degeneration and regeneration exhaust the regenerative ability statellite cells. Mechanisms of fibrosis then induces the gradual replacement of contractile tissue by connective and fatty tissue (Collins \& Morgan 2003, Deconinck \& Dan 2007, Miyazato et al. 2011b, Malvestio et al. 2015). Patients affected by DMD display symptoms of muscle weakness. Rapid progression of DMD begins to occur in affected boys younger than five years of age, affecting muscles of the pelvic girdle and shoulder girdle. Patients also exhibit muscular pseudo-hypertrophy of the calf, kyphosis, scoliosis, and difficulty to ambulate during early childhood. Patients are typically confined to a wheelchair by 14 years of age. By 20 to 30 years of age, patients typically exhibit respiratory and/or cardiac complication, resulting in death (Eagle et al. 2002, Gulati et al. 2005, Van Bockel 2009).

Golden Retriever muscular dystrophy (GRMD) affected dogs are one of the best-known animal models of DMD, with genotypic and phenotypic manifestations similar to the human disease (Cooper et al. 1988, Collins \& Morgan 2003, Moraes et al. 2017). GRMD dogs are the only animals that display early widespread development of secondary lesions due to deficiencies in dystrophin at two months of age. Disease progression in GRMD dogs is comparable to that of DMD affected boys (Nguyen et al. 2002, Banks \& Chamberlain 2008, Lessa et al. 2014a).

Under normal conditions, damage to skeletal muscle due to contractile forces is followed by an inflammatory response, which then subsides after a few days. This transient inflammatory response is a normal homeostatic response to injury that induces muscle repair (Abdel-Salam et al. 2009). Although mutations in dystrophin represent the main cause of DMD, disease progression is exacerbated by secondary processes that are putative for the chronic inflammation. This includes repeated cycles of degeneration and regeneration that deplete the regenerative capacity of satellite cells, and mechanisms that induce the gradual replacement of the contractile muscle tissue by connective and fatty tissue (Collins \& Morgan 2003, Deconinck \& Dan 2007, Miyazato et al. 2011b, Moraes et al. 2015, Moraes et al. 2017). Movement becomes progressively limited, and dogs show premature signs of fatigue (Gaiad et al. 2011).

Mast cells are activated by a series of chemical and physical signals that induces the cytoplasmic release of various factors in a process known as degranulation. These factors act on various sites to increase epithelium and endothelium permeability by stimulating angiogenesis, inducing contraction of smooth muscle, recruiting neutrophils and macrophages, and stimulating fibroblasts to produce collagen (Gorospe et al. 1994, Abbas et al. 2008, Abdel-Salam et al. 2009, Frenzel \& Hermine 2013).

Myocytes lacking dystrophin are more vulnerable to mechanical stress, resulting in the loss of sarcolemmal integrity. Subsequent leakage of cytoplasmic contents stimulates the recruitment of mast cells. DMD affected boys display the first clinical manifestation of dystrophin deficiency at 3 to 5 years of age. In this same period, there is a significant increase in the number of mast cells in the affected muscles, suggesting a causal relationship of mast cells in the pathogenesis of DMD (Gorospe et al. 1994).

It has been suggested that accumulation and subsequent activation of mast cells can result in progression of necrosis and fibrosis, thus resulting in deficient muscle regeneration (Gorospe et al. 1994, Nahirney et al. 1997). In a previous study, mdx mice that received intraperitoneal injections of the mast cell stabilizer cromolyn sodium for 15 days showed reduced myonecrosis in the sternocleidomastoid, anterior tibialis, and diaphragm muscles (Marques et al. 2008).

Therefore, the aim of this study was to evaluate the causal relationship between mast cells and histopathological lesions and the deposition of collagen tissue in four skeletal muscle groups (masseter, diaphragm, brachial, and biceps femoris) of 2 to 8-month-old Golden Retriever dogs affected by muscular dystrophy, in order to establish an inter-relationship of these inflammatory cells in the pathogenesis of fibrosis.

\section{MATERIALS AND METHODS}

Animals. The study was performed using six male GRMD dogs aged 2 to 8 months. Four healthy dogs aged 2 to 8 months were used as controls. These animals were obtained from the GRMD-Brazil Kennel at the "Universidade Estadual Paulista" (Unesp). Elevation of serum creatine kinase (CK) was used initially to identify the dogs with dystrophy. Subsequent PCR genotyping was used to confirm the phenotypes (Miyazato et al. 2011b). Respiratory and/or cardiac complications resulted in death in all GRMD dogs. This research was approved by the Ethical Principles of Animal Experimentation adopted by the "Ethics in the use of animals" at the Unesp (protocol no. $01465 / 15$ ).

Histopathological and morphometric analysis. For analysis study the samples of skeletal muscles masseter, diaphragm, brachial triceps and biceps femoris of the GRMD and of the controls dogs with aged 2, 3, 5 and 8 months were collected, fixed in $10 \%$ phosphate buffered formalin, embedded in paraffin, and sectioned at $3 \mu \mathrm{m}$. Sections were stained with hematoxylin and eosin (HE; histopathology), toluidine blue (identification of mast cells) and Azan trichrome (evaluation of fibrosis) by using standard procedures (Miyazato et al. 2011b).

Morphometric analysis in the number of mast cells was obtained from 50 random fields of the samples (Nahirney et al. 1997) and quantified by automatic sequential numerator KW-TRIO ${ }^{\circledR}$ in a Zeiss Primo Star light microscope (40x objective). 
Quantitation of the collagen fibers was performed in 10 random fields of muscle fragments according to Prado et al. (2012). Microscopy was performed on the Leica ${ }^{\circledR}$ DMR light microscope (DFC camera 290) and analyzed with the Leica ${ }^{\circledR}$ Qwin V3 software.

Statistical analysis. Data were analyzed using GraphPad Prism 5 (GraphPad Software Inc., San Diego/CA). The Kolmogorov-Smirnov test was used to examine normality. Multiple comparisons were performed by analysis of variance (ANOVA) and Tukey's test at the significance level of $5 \%$ and a correlation between collagen-mast cells of the muscles of dogs was analyzed by the method Pearson's (5\%).

\section{RESULTS}

\section{Histopathology}

Histological analysis of muscle samples from control dogs displayed normal muscle patterns, as demonstrated by uniformly distributed muscle fibers with normal diameter, and polyhedral shape surrounded by connective tissue and peripheral cores (Fig.1A and 2A).

However, histological analysis of muscle samples from GRMD dogs revealed degenerative alterations and variations in fiber diameter, infiltration of interfascicular fat cells, and interstitial fibrosis. Necrosis was more frequent in the diaphragm, brachial triceps, and biceps femoris, while less frequent in the masseter. Hyalinization was the most frequent alteration in the masseter, diaphragm, and triceps, while less frequent in the biceps femoris muscle. Inflammatory infiltration of mononuclear cells, particularly giant cells in the interstitium or around the fascicles was more pronounced in the triceps, biceps femoris, and masseter, in contrast to the diaphragm.

Analysis of muscle samples from GRMD dogs revealed mast cells predominantly in fibrotic areas, including the arterioles, venules, and endomysium (Fig.1B and 1C). Azan trichrome staining revealed deposition of collagenous tissue (blue) in the perimysium and endomysium in GRMD dogs (Fig.2B and 2C).

\section{Morphometric analysis of fibro-collagenous and tissue mastocytes}

Quantification in the number of mast cells was performed in 40 samples. The highest average count in mast cells was observed in triceps, followed by femoral biceps and masseter muscle $(p<0.05)$. The lowest count was observed in diaphragm $(p<0.05)$. The concentration of mast cells in the muscle groups of affected animals varied in relation to age group. In all muscle groups, the number of mast cells increased preferentially in the endomysium of younger GRMD dogs. In GRMD dogs, a significant increase in the amount of the infiltrating mast cells was observed, as compared to the control group $(\mathrm{p}<0.05)$ (Fig.3).

Significant deposition of fibro-collagenous tissue was observed in all GRMD dog muscle samples. The triceps had
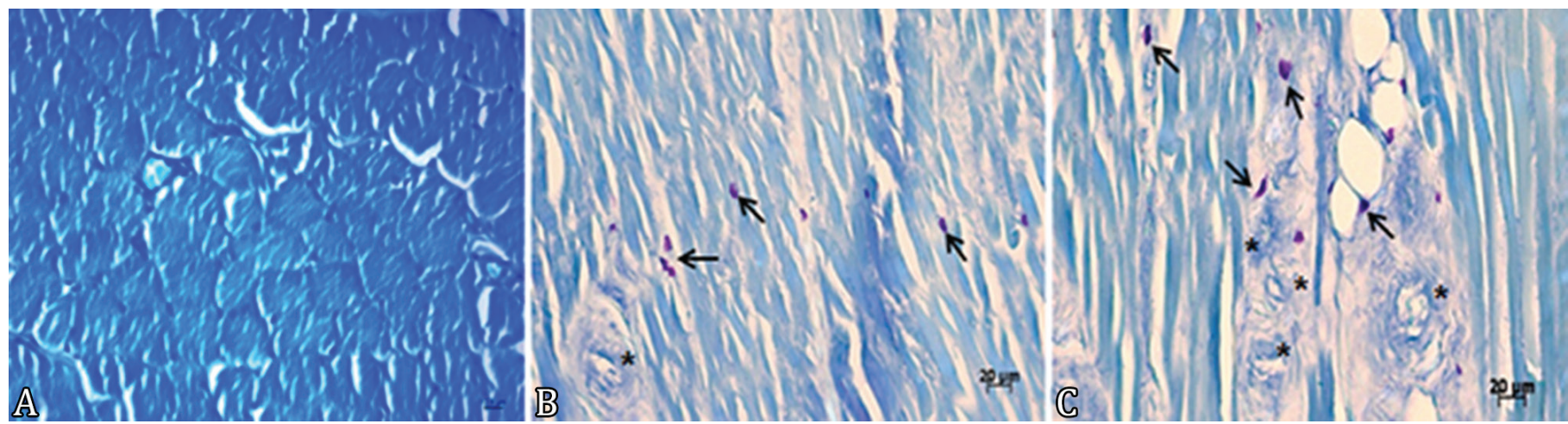

Fig.1. Mast cells in skeletal muscle samples from 2-month-old GRMD dogs. (A) Diaphragm. Animal control, muscle fibers distributed with regular diameter. (B) Brachial triceps. Presence of mast cells (arrow) in areas of fibrosis and near a venule $(*)$. (C) Biceps femoris. Presence of mast cells (arrow) in areas of fibrosis, fatty infiltration, arterioles and venules (*). Toluidine blue, bar $=20 \mu \mathrm{m}$.
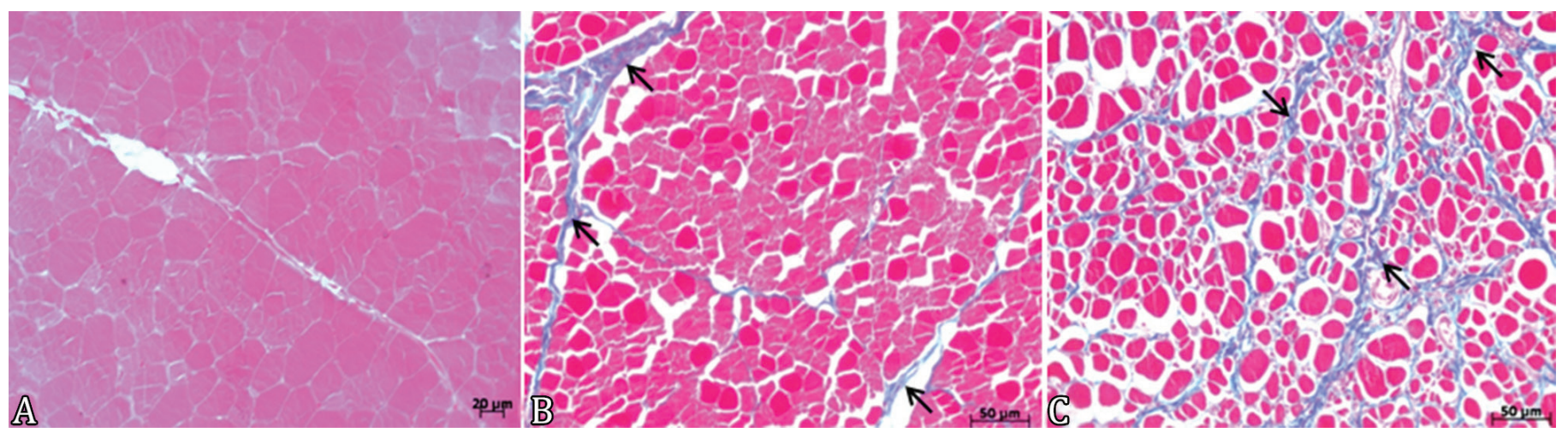

Fig.2. Fibro-collagenous tissue in skeletal muscle samples from GRMD dogs. (A) Masseter. Animal control, muscle fibers distributed with regular diameter. Azan trichrome, bar $=20 \mu \mathrm{m}$. (B) Masseter. Mild deposition of fibro-collagenous tissue (arrow) in epimysium and endomysium in an 8-month-old dog. Azan trichrome, bar $=50 \mu \mathrm{m}$. (C) Biceps Femoris. Intense deposition of fibro-collagenous tissue (arrow) in the endomysium in a 2-month-old dog. Azan trichrome, bar $=50 \mu \mathrm{m}$. 


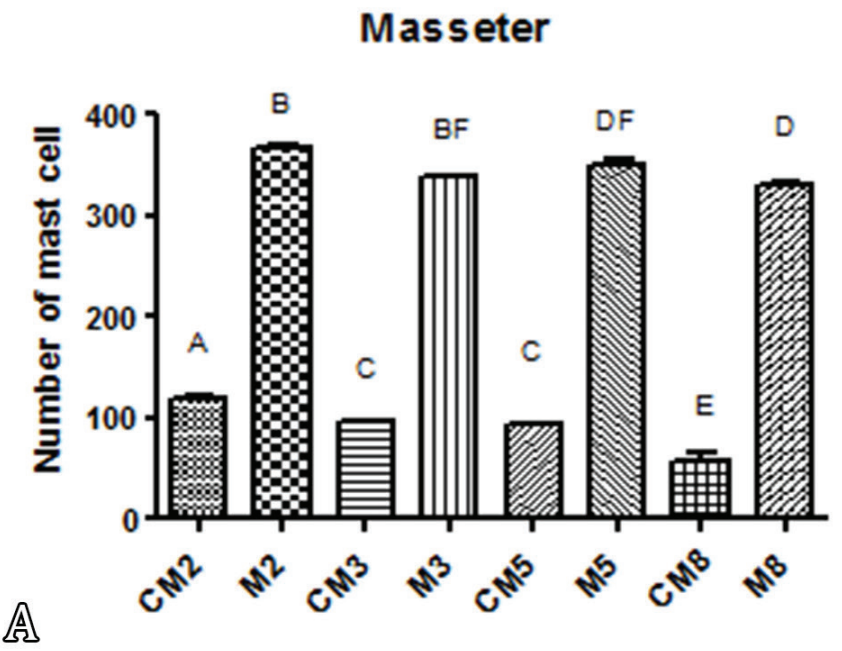

Brachial Triceps

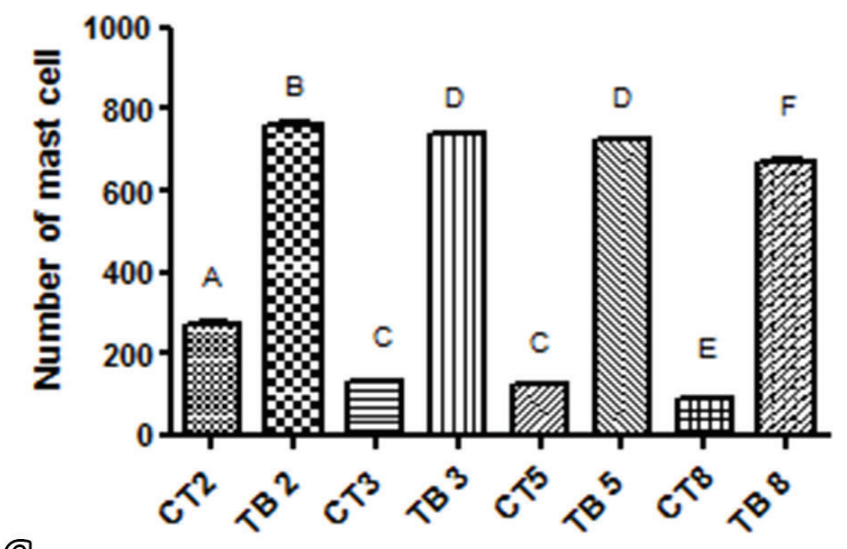

Diaphragm

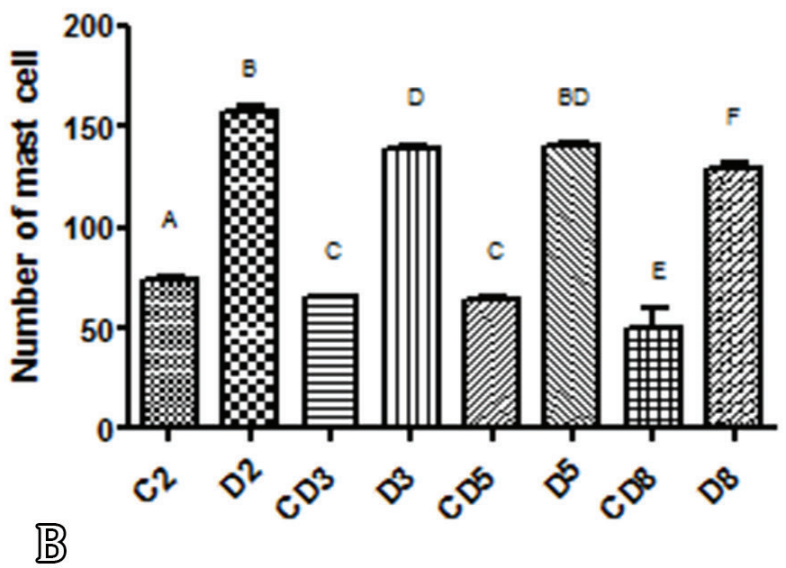

Biceps Femoris

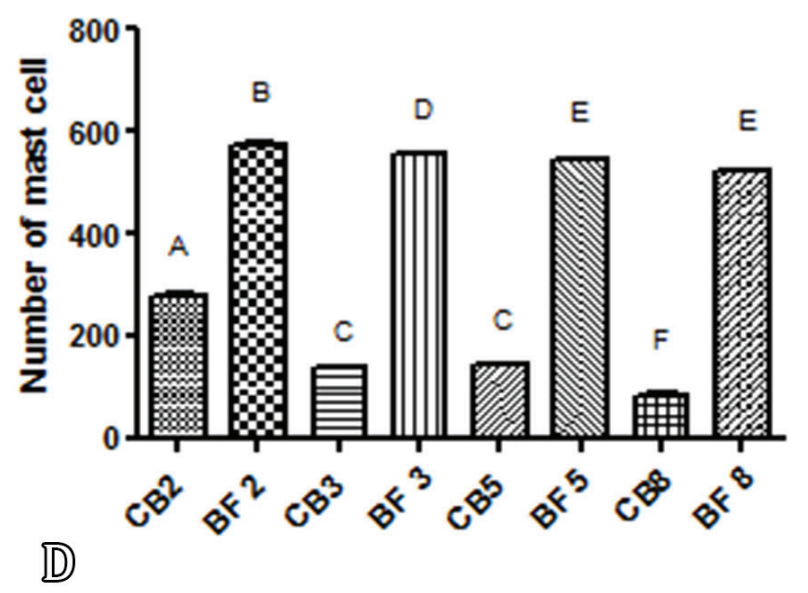

Fig.3. Number of mast cells in (A) Masseter (M) and Masseter control group (CM), (B) diaphragm (D) and diaphragm control group (CD), (C) brachial triceps (TB) and brachial triceps control group (CT), (D) biceps femoris (BF) and biceps femoris control group (CF) from GRMD dogs aged 2, 3, 5 and 8 months respectively. Vertical columns represent means of each group in the sampling times. Columns with letters in common do not differ by Tukey's test $(\mathrm{p}<0.05)$.

the highest amounts of this tissue, followed by biceps femoris, diaphragm, and masseter. The amount of fibro-collagenous tissue varied in relation to the muscle group and age group in all muscle groups studied. When compared to the control group, GRMD dogs had a significant increase in the amount of collagenous tissue in all muscle groups $(\mathrm{p}<0.05)$, as measured in percentage of tissue per field (Fig.4). It was observed a correlation $(\mathrm{p}<0.05)$ between collagen and mast cells in the muscles of these dogs, it was verified one stronger linear correlation in triceps with dystrophy in animals of 2 and 3 months of age, both $r=0.99$ and coefficient of determination $\left(r^{2}\right)$ in 0.98 and 0.99 , respectively (Table 1$)$. In biceps femoris resembled $\left(r=0.95, r^{2}=0.90\right)$ (Table 1$)$.

\section{DISCUSSION}

In this study, GRMD dogs from 2 to 8 months in age have been characterized by variations in muscle fiber diameter, necrosis, hyalinization, mononuclear cells infiltration, fatty infiltration, and interstitial fibrosis in four muscle groups: the masseter, diaphragm, triceps, and biceps femoris. These observations are consistent with previously published studies of GRMD dogs of different ages (Beretta et al. 2014, Miyazato et al. 2011a, 2011b).

Our results suggest the masseter muscle presented a lower incidence of injuries among the four muscles evaluated. Minimal degeneration of the masseter may be due to smaller muscle fiber diameters and minimal exposure to mechanical stress as compared to muscles located in the fore and hind limbs (Lee et al. 2006).

We observed an increase in the number of mast cells in dystrophic animals compared to control group animals. This is consistent with a previous study of DMD patients with a mean age of 41 months, where an increase in the number of mast cells was observed compared to control group. These mast cells were immuno-positive for neural growth factor (NGF), while it was negative for other inflammatory cells such as lymphocytes and macrophages (Toti et al. 2003). Quantification of mast cells revealed a higher number of mast cells in the triceps, biceps 


\section{Masseter}

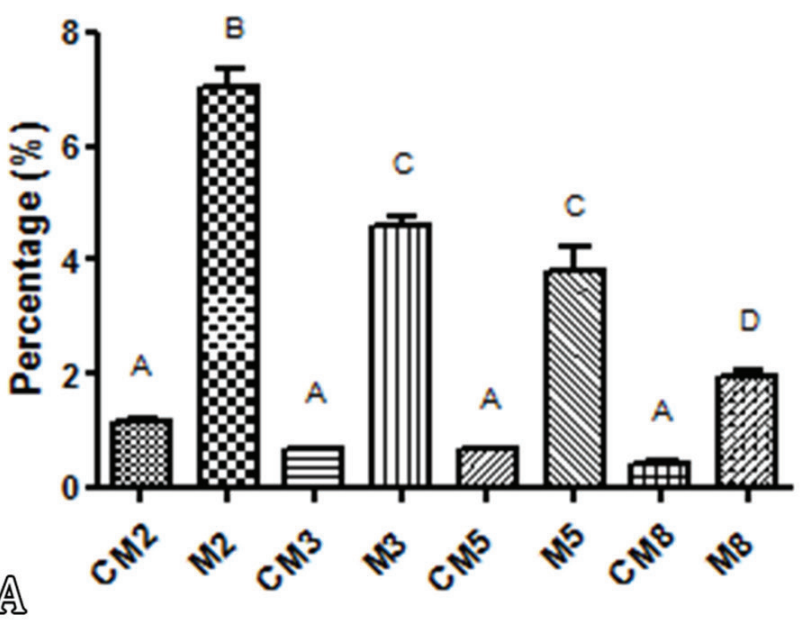

Brachial T riceps

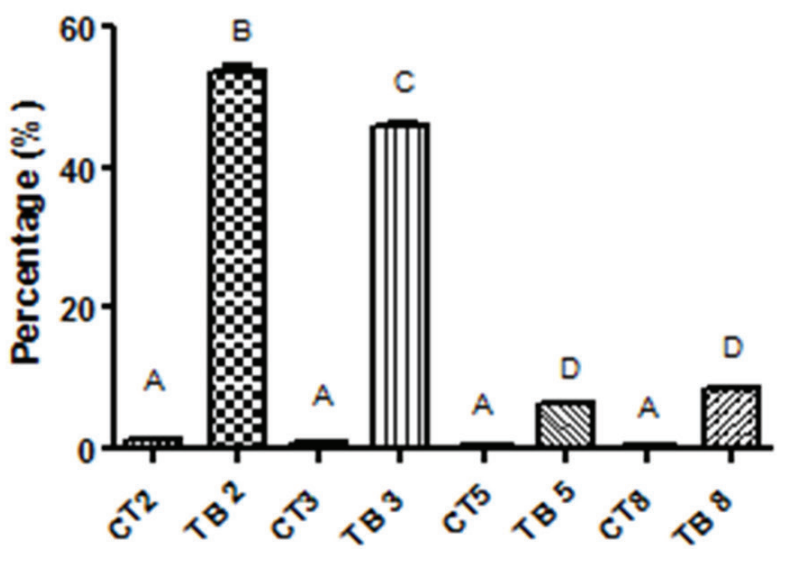

Diaphragm

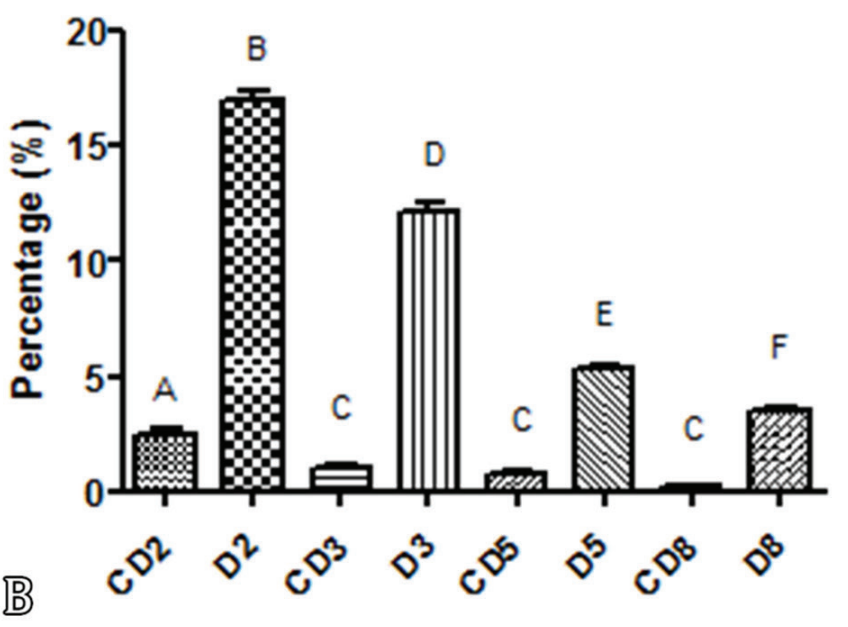

Biceps Femoris

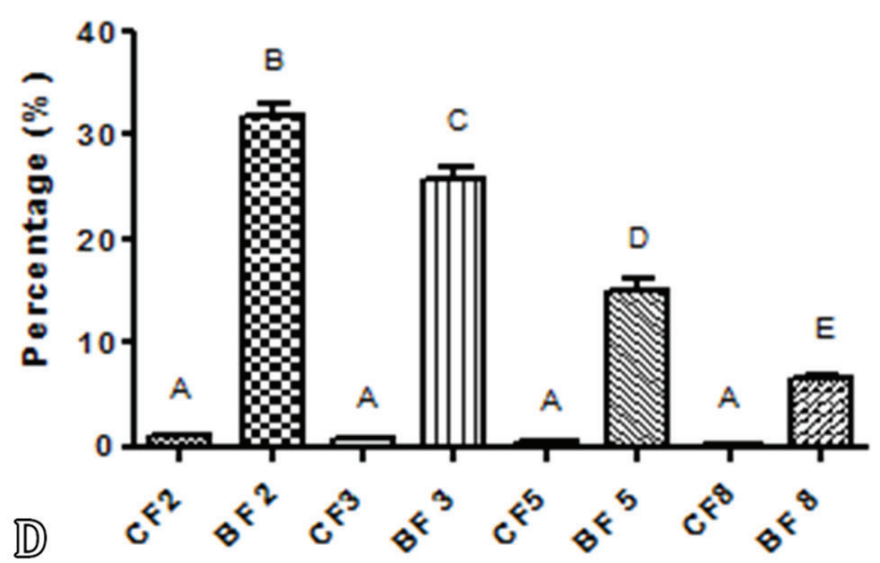

Fig.4. Deposition of fibro-collagenous tissue in (A) Masseter (M) and Masseter control group (CM), (B) diaphragm (D) and diaphragm control group (CD), (C) brachial triceps (TB) and brachial triceps control group (CT), (D) biceps femoris (BF) and biceps femoris control group (CF) from GRMD dogs aged 2, 3, 5 and 8 months respectively. Vertical columns represent means of each group in the sampling times. Columns with letters in common do not differ by Tukey's test $(\mathrm{p}<0.05)$.

Table 1. Ratio fibro-collagenous-mast cells in skeletal muscle samples from golden retriever muscular dystrophy dogs of four times and control

\begin{tabular}{|c|c|c|c|c|c|c|c|c|c|}
\hline \multirow{3}{*}{ Treatments } & & \multicolumn{8}{|c|}{ Age of animals } \\
\hline & & \multicolumn{2}{|c|}{2 months } & \multicolumn{2}{|c|}{3 months } & \multicolumn{2}{|c|}{5 months } & \multicolumn{2}{|c|}{8 months } \\
\hline & & $\mathrm{D}$ & $\mathrm{C}$ & $\mathrm{D}$ & $\mathrm{C}$ & $\mathrm{D}$ & $\mathrm{C}$ & $\mathrm{D}$ & $\mathrm{C}$ \\
\hline \multirow[t]{3}{*}{ Masseter } & $\mathrm{r}$ & 0.36 & $-1.0-$ & 0.39 & $0.6-$ & $0.79-$ & 0.14 & 0.50 & $-0.33-$ \\
\hline & $r^{2}$ & 0.13 & 0.01 & 0,15 & 0.4 & 0.63 & 0.02 & 0.50 & 0.11 \\
\hline & $\mathrm{p}$-value & $p>0.05$ & $\mathrm{p}>0.05$ & $\mathrm{p}>0.05$ & $\mathrm{p}>0.05$ & $p>0.05$ & $p>0.05$ & $p>0.05$ & $\mathrm{p}>0.05$ \\
\hline \multirow[t]{3}{*}{ Diaphragm } & r & - 0.57 - & $-0.50-$ & $0.92-$ & 0.31 & 0.90 & $-0.08-$ & 0.96 & 0.98 \\
\hline & $r^{2}$ & 0.32 & 0.30 & 0.86 & 0.09 & 0.81 & 0.007 & 0.92 & 0.97 \\
\hline & $\mathrm{p}$-value & $\mathrm{p}>0.05$ & $p>0.05$ & $p>0.05$ & $\mathrm{p}>0.05$ & $p>0.05$ & $p>0.05$ & $p>0.05$ & $p>0.05$ \\
\hline \multirow[t]{3}{*}{ Brachial triceps } & $\mathrm{r}$ & $0.99-$ & $0.70-$ & 0.99 & 0.57 & $0.90-$ & 0.8 & $-0.096-$ & 0.2 \\
\hline & $\mathrm{r}^{2}$ & 0.98 & 0.50 & 0.99 & 0.33 & 0.94 & 0.7 & 0.092 & 0.05 \\
\hline & p-value & $\mathrm{p}<0.05$ & $p>0.05$ & $\mathrm{p}<0.05$ & $\mathrm{p}>0.05$ & $p>0.05$ & $p>0.05$ & $p>0.05$ & $\mathrm{p}>0.05$ \\
\hline \multirow[t]{3}{*}{ Biceps femoris } & $\mathrm{r}$ & 0.95 - & $0.60-$ & 0.70 & 0.99 - & $-0.64-$ & - 0.7 - & 0.79 & $0.82-$ \\
\hline & $r^{2}$ & 0.90 & 0.30 & 0.50 & 0.99 & 0.41 & 0.51 & 0.63 & 0.6 \\
\hline & p-value & $p>0.05$ & $\mathrm{p}>0.05$ & $p>0.05$ & $\mathrm{p}<0.05$ & $p>0.05$ & $p>0.05$ & $\mathrm{p}>0.05$ & $\mathrm{p}>0.05$ \\
\hline
\end{tabular}

$\mathrm{D}=$ Animals with dystrophy, $\mathrm{C}=$ control; $\mathrm{r}$ = Pearson's correlation coefficient with significance, $\mathrm{r} 2$ = coefficient of determination. 
femoris, and masseter of 2-month-old dogs. These muscles are more severely affected by the inflammatory process in younger animals due to high usage and activity during the post-natal period (Valentine \& Cooper 1991, Nguyen et al. 2002, Miyazato 2010), thereby suggesting a direct relationship between muscle degeneration and the number of mast cells.

We also observed a decrease in the average number of mast cells and percentage of deposition of collagenous tissue the diaphragm, indicating a lower degree of lesion in this muscle. This is consistent with a previous study, in which eleven muscles from GRMD dogs of varying ages revealed that the diaphragm was the least affected muscle, while showing a greater regenerative capacity similar to the masseter muscle (Miyazato 2010). However, the diaphragm of human DMD patients is the most affected muscle in adulthood. These structural deformities likely result from confinement to a wheelchair (Lessa etal. 2014b). Therefore, the degree of lesion in the diaphragm of DMD patients could be associated with age. In GRMD dogs, this occurs in younger animals, in contrast to DMD patients of older age.

Furthermore, another study showed that 3-month-old GRMD dogs displayed a higher number of mast cells in the peroneus longus muscle as compared to 6-month-old GRMD dogs. Comparatively, 6-month-old GRMD dogs correspond to 11-year-old patients with DMD (Gorospe et al. 1994), a period for which a wheelchair is typically needed (Gorospe et al. 1994). The degree of lesions may be related to inflammatory response and muscle activity, since patients in wheelchairs had limited movement (Gorospe et al. 1994).

Another study showed, the 12-week physical therapy protocol consisting of active exercises 3 times a week for 40 minutes with rest intervals demonstrated negative effects on walking speed and increased the amount of type I collagen in 5-months-old dystrophic dogs (Gaiad et al. 2014). The degree of injury may be related to inflammatory response, as well as muscle activity, since patients in wheelchairs reduce the movement of members.

The interrelationship of mast cells in the pathogenesis of fibrosis in GRMD dogs is poorly understood. In this study, we observed fibrosis in animals as early as 2 months of age. Previous studies with GRMD dogs of varying ages displayed significant increases in the deposition of fibrous tissue in the quadriceps and tibialis anterior muscles (Cozzi et al. 2001). However, no increase of fibrous tissue deposition in relation to age was observed. The dystrophic process, including replacement of muscle by fibrotic tissue, was evident in 15 days old animals, well before the completion of the muscle maturation (Cozzi et al. 2001). This is in contrast to that observed in DMD patients, in which fibrosis deposition is correlated with age (Cozzi et al. 2001). Decreased fibrosis with the increase in age may be due to depletion of muscle potential, followed by repeated cycles of degeneration and regeneration (Cozzi et al. 2001). The extent of proliferation of the connective tissue is also variable in DMD patients, despite the fact that fibrosis generally increases with the progression of the disease.

The first stage after muscle injury is the formation of hematoma between damaged fibers that is rapidly invaded by inflammatory cells and cytokines. In addition to stimulating the functions of satellite cells, these molecules also induce massive proliferation and activation of fibroblasts. Fibrosis is the aberrant deposition of extracellular matrix (ECM) during the healing, DMD and some other muscular pathologies, it might ultimately lead to substitution of skeletal and cardiac muscle by fibrous tissue (Serrano \& Muñoz-Cánoves 2010, Serrano et al. 2011). An alternative explanation this study could be that higher mast cells track with overall inflammation and edema, which could potentially expand the extracellular space, including the interstitium (endomysium and perimysium). However, in older dogs, you would no longer expect to see this degree of active disease.

Current pharmacological study evaluated the bortezomib an inhibitor of the ubiquitin-proteasome pathway associated with degradation of the dystrophin-glycoprotein complex (DGC). Study has shown a decrease in the deposition of fibrous tissue and inflammatory cells in the skeletal muscle of 4-months-old GRMD dogs treated for 4 weeks with bortezomib. However, in this study CK levels presented altered indicating that the disease progressed despite treatment (Araujo et al. 2013).

Our findings confirm the hypothesis that mast cells are more numerous muscles containing defective dystrophin, as well as participate in the histopathologic characterization of lesions and deposition of collagenous tissue in the muscle fibers. The femoral biceps, triceps, and masseter displayed a higher average number of mast cells and minor lesions, thus suggesting a direct relationship between the intensity of the injury and the number of mast cells.

\section{CONCLUSIONS}

The results demonstrate a direct relationship between the histopathological lesions and the number of mast cells and collagen fibers in skeletal muscle of four groups of dogs GRMD from 2 to 8 months of age. The age group of 2 months presented the highest average number of mast cells and collagenous tissue deposition and in contrast the age of 8 months presented the lowest average number and lowest deposition of fibrous tissue.

Nevertheless, more studies are needed to clarify the role of mast cells in the pathogenesis of fibrosis in order to contribute to the development of new therapeutic approaches and improve the life expectancy of humans and dogs affected by muscular dystrophy.

Acknowledgments.- The authors are grateful for the support of the "Fundação de Amparo à Pesquisa do Estado de São Paulo" (FAPESP), grant number 13/25957-6 and "Coordenação de Aperfeiçoamento de Pessoal de Nível Superior” (CAPES).

Conflict of interest statement.- The authors have no competing interests.

\section{REFERENCES}

Abbas A.K., Lichtman A.H. \& Pillai S. 2008. Hipersensibilidade imediata, p.442-461. In: Abbas A.K. (Ed.), Imunologia Celular e Molecular. 6a ed. Elsevier, Rio de Janeiro.

Abdel-Salam E., Abdel-Meguid I. \& Korraal S.S. 2009. Markers of degeneration and regeneratio in Duchenne muscular dystrophy. Acta Myol. 28(3):94-100. <PMid:20476668>

Araujo K.P.C., Bonucelli G., Duarte C.N., Gaiad T.P., Moreira D.F., Feder D., Belizario J.E., Miglino M.A., Lisanti M.P. \& Ambrosio C.E. 2013. Bortezomid (PS-341) treatment decreases inflammation and partially rescues the expression of the dystrophin-glycoprotein complex in GRMD dogs. Plos One 8(4):e61367. <https://dx.doi.org/10.1371/journal.pone.0061367> <PMid:23579193>

Banks G.B. \& Chamberlain J.S. 2008. The value of mammalian models for duchenne muscular dystrophy in developing therapeutic strategies. Curr. Top. Dev. Biol. 84:431-453. <https://dx.doi.org/10.1016/S00702153(08)00609-1><PMid:19186250> 
Beretta D.C., Moraes J.R.E., Engracia-Filho J.R., Malvestio L.M.M. \& Moraes F.R. 2014. Immunohistochemical and morphometric evaluation of gastrocnemius muscle and myotendinous junction of Golden Retriever dogs with muscular dystrophy. Braz. J. Vet. Pathol. 7(2):70-81.

Collins C.A. \& Morgan J.E. 2003. Duchenne's muscular dystrophy: animal models used to investigate pathogenesis and develop therapeutic strategies. Int. J. Exp. Pathol. 84(4):165-172.<https://dx.doi.org/10.1046/j.1365-2613.2003.00354.x> $<$ PMid:14632630>

Cooper B.J., Winand N.J. \& Stedman H., Valentine B.A., Hoffman E.P., Kunkel L.M., Marion-Oronzi S., Fischbeck K.H., Kornegay J.N., Avery R.J., Williams J.R., Schmickel R.D. \& Sylvester J.E. 1988. The homologue of the Duchenne locus is defective in X-linked muscular dystrophy of dogs. Nature 334:154156. <https://dx.doi.org/10.1038/334154A0>

Cozzi F., Cerletti M., Luvoni G.C., Lombardo R., Brambilla P.G., Faverzani S., Blasevich F., Cornelio F., Pozza O. \& Mora M. 2001. Development of muscle pathology in canine X-linked muscular dystrophy. II. Quantitative characterization of histopathological progression during postnatal skeletal muscle development. Acta Neuropathol. 101(5):469-478. <https://dx.doi. org/10.1007/s004010000308> <PMid:11484818>

Deconinck N. \& Dan B. 2007. Pathophysiology of Duchenne muscular dystrophy: current hypotheses. Pediatr. Neurol. 36(1):1-7.<https://dx.doi. org/10.1016/j.pediatrneurol.2006.09.016><PMid:17162189>

Eagle M., Baudouin S.V., Chandler C., Giddings D.R., Bullock R. \& Bushby K. 2002. Survival in Duchenne muscular dystrophy: Improvements in life expectancy since 1967 and the impact of home nocturnal ventilation. Neuromuscul. Disord. 12(10):926-929. <https://dx.doi.org/10.1016/ s0960-8966(02)00140-2><PMid:12467747>

Frenzel L. \& Hermine 0. 2013. Mast cells and inflammation. Joint Bone Spine 80(2):141-145. <https://dx.doi.org/10.1016/j.jbspin.2012.08.013> $<$ PMid:23116710>

Gaiad T.P., Araujo K.P.C., Serrão J.C., Miglino M.A. \& Ambrosio C.E. 2014. Motor physical therapy affects muscle collagen type I and decreases gait speed in dystrophin-deficient dogs. Plos One 9(4):1-9. <https://dx.doi. org/10.1371/journal.pone.0093500><PMid:24713872>

Gaiad T.P., Silva M.B., Silva G.C.A., Caromano F.A., Miglino M.A. \& Ambrósio C.E. 2011. Physical therapy assessment tools to evaluate disease progression and phenotype variability in Golden Retriever muscular dystrophy. Res. Vet. Sci. 91(2):188-193.<https://dx.doi.org/10.1016/j.rvsc.2011.01.007> <PMid:21315399>

Gorospe J.R.M., Tharp M.D., Hinckley J., Kornegay J.N. \& Hoffman E.P. 1994. The role for mast cells in the progression of Duchenne muscular dystrophy? Correlations in dystrophin-deficient humans, dogs, and mice. J. Neurol. Sci. 122(1):44-56. <https://dx.doi.org/10.1016/0022-510X(94)90050-7>

Gulati S., Saxena A., Kumar V. \& Kalra V. 2005. Duchenne muscular dystrophy: prevalence and patterns of cardiac involvement. Indian J. Pediatr. 72(5):389393. <https://dx.doi.org/10.1007/BF02731732><PMid:15973020>

Hoffman E.P., Brown-Junior R.H. \& Kunkel LM. 1987. Dystrophin: the protein product of the Duchenne muscular dystrophy locus. Cell 51(6):919-928. <https://dx.doi.org/10.1016/0092-8674(87)90579-4><PMid:3319190>

Lee W.H., Abe S., Kim H.J., Usami A., Honda A., Sakiyama K. \& Ide Y. 2006. Characteristics of muscle fibers reconstituted in the regeneration process of masseter muscle in an mdx mouse model of muscular dystrophy. J. Muscle Res. Cell Motil. 27(3/4):235-240. <https://dx.doi.org/10.1007/ s10974-006-9066-5><PMid:16752197>

Lessa T.B., Abreu D.K., Rodrigues M.N., Brólio M.P., Miglino M.A. \& Ambrósio C.E. 2014a. Morphological and ultrastructural evaluation of the Golden Retriever muscular dystrophy trachea, lungs, and diaphragm muscle. Microsc. Res. Tech. 77(11):857-861. <https://dx.doi.org/10.1002/ jemt.22408> <PMid:25081087>

Lessa T.B., Carvalho R.C., Spagnolo J.D., Silva L.C., Cortopassi S.R. \& Ambrósio C.E. 2014b. Laparoscopic guided local injection in the X-linked muscular dystrophy mouse (mdx) diaphragm. An advance in experimental therapies for Duchenne muscular dystrophy. Acta Cir. Bras. 29(11):715-720. <https://dx.doi.org/10.1590/S0102-86502014001800004>
Malvestio L.M.M., Martins I.M., Moares F.R. \& Moraes J.R.E. 2015. Histopathologic evolution of cardiomyopathy in a canine model of Duchenne muscular dystrophy. J. Advanc. Vet. Res. 5(3):121-126.

Marques M.J., Machado R.V., Minatel E. \& Santo-Neto H. 2008. Disodium cromoglycate protects dystrophin-deficient muscle fibers from leakiness. Muscle Nerve 37(1):61-67 <https://dx.doi.org/10.1002/mus.20892> <PMid:17724738>

Miyazato L.G., Beretta D.C., Engracia-Filho J.R., Moraes F.R. \& Moraes J.R.E. 2011a. Evaluation of intracellular calcium in Golden Retriever muscular dystrophy. Braz. J. Vet. Pathol. 4(2):95-102.

Miyazato L.G., Beretta D.C., Engracia-Filho J.R., Moraes F.R. \& Moraes J.R.E. 2011b. Involvement of organic systems in golden retriever X-linked muscular dystrophy. Braz. J. Vet. Pathol. 4(2):87-94.

Miyazato L.G. 2010. Histopatologia e imunoistoquímica na Distrofia Muscular do Golden Retriever. Doctoral Dissertation, Faculdade de Ciências Agrárias e Veterinárias, Universidade Estadual Paulista, Jaboticabal. 89p.

Moraes J.R.E., Malvestio L.M.M., Martins I.M. \& Moraes F.R. 2015. The value of dog for knowledge of human Duchenne muscular dystrophy: New findings in pathogenesis and therapeutic advances, p.141-153. In: Honório S.A.A. (Ed.), Duchenne Muscular Dystrophy: symptoms, management and prognosis. Nova Science Publishers, New York.

Moraes J.R.E., Malvestio L.M.M., Martins I.M., Mosko P.R.E, Engracia-Filho J.R. \& Moraes F.R. 2017. Relevant aspects of Golden retriever muscular dystrophy for the study of Duchenne muscular dystrophy in humans. Ciência Rural 47(10):1-11.<https://dx.doi.org/10.1590/0103-8478cr20160470>

Nahirney P.C., Dow P.R. \& Ovalle W.K. 1997. Quantitative morphology of mast cells in skeletal muscle of normal and genetically dystrophic mice. Anat. Rec. 247(3):341-349. <https://dx.doi.org/10.1002/(SICI)10970185(199703)247:3<341::AID-AR5>3.0.C0;2-X><PMid:9066911>

Nguyen F., Cherel Y., Guiand L., Goubault-Leroux I. \& Wyers M. 2002. Muscle lesions associated with dystrophin deficiency in neonatal golden retriever puppies. J. Comp. Pathol. 126(2/3):100-108. <https://dx.doi.org/10.1053/ jcpa.2001.0526><PMid:11944998>

Prado C.M., Celes M.R.N., Malvestio L.M., Campos E.C., Silva J.S., Jelicks L.A., Tanowitz H.B. \& Rossi M.A. 2012. Early dystrophin disruption in the pathogenesis of experimental chronic chagas cardiomyopathy. Microbes Infect. 14(1):59-68. <https://dx.doi.org/10.1016/j.micinf.2011.08.010>

Serrano A.L. \& Muñoz-Cánoves P. 2010. Regulation and dysregulation of fibrosis in skeletal muscle. Exp. Cell Res. 316(18):3050-3058. <https://dx.doi.org/10.1016/j.yexcr.2010.05.035><PMid:20570674>

Serrano A.L., Mann C.J., Vidal B., Ardite E., Perdiguero E. \& Muñoz-Cánoves P. 2011. Cellular and molecular mechanisms regulating fibrosis in skeletal muscle repair and disease. Curr. Top. Dev. Biol. 96:167-282. <https://dx.doi.org/10.1016/B978-0-12-385940-2.00007-3><PMid:21621071>

Toti P., Villanova M., Vatti R., Schuerfeld K., Stumpo M., Barbagli L., Malandrini A. \& Costantini M. 2003. Nerve growth fator expression in human dystrophic muscles. Muscle Nerve 27(3):370-373. <https://dx.doi.org/10.1002/ mus.10332> <PMid:12635125>

Valentine B.A. \& Cooper B.J. 1991. Canine X-linked muscular dystrophy: selective involvement of muscles in neonatal dogs. Neuromuscul. Disord. 1(1):31-38. <https://dx.doi.org/10.1016/0960-8966(91)90040-Y>

Van Bockel E.A., Lind J.S., Zijlstra J.G., Wijkstra P.J., Meijer P.M., Van den Berg M.P., Slart R.H., Aarts L.P. \& Tulleken J.E. 2009. Cardiac assessment of patients with late stage Duchenne muscular dystrophy. Neth. Heart J. 17(6):232237. <https://dx.doi.org/10.1007/BF03086253><PMid:19789685>

Woolf P.J., Lu S., Cornford-Nairn R., Watson M., Xiao X.H., Holroyd S.M., Brown L. \& Hoey A.J. 2006. Alterations in dihydropyridine receptors in dystrophin-deficient cardiac muscle. Am. J. Physiol. Heart Circ. Physiol. 290(6):2439-2445. <https://dx.doi.org/10.1152/ajpheart.00844.2005> $<$ PMid:16415078> 